\title{
Is Occurrence of Harmful Algal Blooms in the Exclusive Economic Zone of India on the Rise?
}

\author{
K. B. Padmakumar, ${ }^{1}$ N. R. Menon, ${ }^{2}$ and V. N. Sanjeevan ${ }^{1}$ \\ ${ }^{1}$ Centre for Marine Living Resources and Ecology, Ministry of Earth Sciences, Kochi 37, Kerala, India \\ ${ }^{2}$ School of Marine Sciences, Cochin University of Science and Technology and Nansen Environmental Research Center, \\ Kochi 16, Kerala, India \\ Correspondence should be addressed to K. B. Padmakumar, kbpadmakumar@gmail.com
}

Received 4 November 2011; Revised 30 December 2011; Accepted 13 January 2012

Academic Editor: Robert Frouin

Copyright (๑) 2012 K. B. Padmakumar et al. This is an open access article distributed under the Creative Commons Attribution License, which permits unrestricted use, distribution, and reproduction in any medium, provided the original work is properly cited.

Occurrence, increase in frequency, intensity and spatial coverage of harmful algal blooms during the past decade in the EEZ of India are documented here. Eighty algal blooms were recorded during the period 1998-2010. Of the eighty algal blooms, 31 blooms were formed by dinoflagellates, 27 by cyanobacteria, and 18 by diatoms. Three raphidophyte and one haptophyte blooms were also observed. Potentially toxic microalgae recorded from the Indian waters were Alexandrium spp., Gymnodinium spp. Dinophysis spp., Coolia monotis, Prorocentrum lima, and Pseudo-nitzschia spp. Examination of available data from the literature during the last hundred years and in situ observations during 1998-2010 indicates clear-cut increase in the occurrence of HABs in the Indian EEZ.

\section{Introduction}

The International Council for the Exploration of the Seas [1] has defined phytoplankton blooms as, those, which are noticeable, particularly to general public, directly or indirectly through their effects such as visible discolouration of the waters, foam production, and fish or invertebrate mortality or toxicity to humans. Among around 5000 species of marine phytoplankton, around 300 species including diatoms, dinoflagellate, raphidophytes, prymnesiophytes, cyanophytes, and silicoflagellates can at times cause algal blooms. Only a few dozen of these species have the ability to produce potent toxins. Harmful Algal Blooms (HABs) are global phenomenon, reported from over 30 countries including India. Number of HABs, economic losses from them, the types of resources affected, and number of toxins and toxic species have also increased dramatically in recent years [2-4].

The first recorded observation on algal blooms in Indian waters is by Hornell in 1908 [5]. He witnessed massive fish mortality, largely of sardines floating on the dark yellow coloured water that contained plankton. In 1916, he found
Euglena and Noctiluca species to be responsible for such episodes. Subrahmanyan [6] identified this organism as Hornellia marina, and later in 1982 Hara and Chihara [7] reclas-sified this as the raphidophyte Chattonella marina. Since then, there have been several reports on various algal blooms dominated by blooms of Noctiluca scintillans $(=N$. miliaris) and Trichodesmium spp. from the EEZ of India. Episodic observations on algal blooms were reported from 1917 onwards.

First record of Paralytic Shellfish Poisoning (PSP) was during 1981 from coastal Tamilnadu, Karnataka, and Maharashtra [8]. In 1981, PSP resulted in death of 3 persons and hospitalization of 85 people due to consumption of affected mussel Meretrix casta in Tamilnadu. An outbreak of PSP has occurred in Kumbla near Mangalore following consumption of clams in 1983 [9]. Godhe and Karunasagar [10] reported Gymnodinium catenatum, a potent PSP producing alga in both plankton samples and cysts in sediments from the coastal waters of Mangalore. In September 1997, an outbreak of PSP was reported from Vizhinjam, Kerala, resulting in the death of seven persons and hospitalization of over 500 following consumption of mussel, Perna 
indica [11]. Recently, in September 2004, an unusual nauseating smell emanating from the coastal waters was recorded from Kollam to Vizhinjam in the southwest coast of India. More than 200 persons, especially children, complained of nausea and breathlessness for short duration due to the smell. This coincided with massive fish kills in this region. The causative organism was Cochlodinium polykrikoides. Several publications are available dealing with different types of blooms in the Indian EEZ. The frequency and extend of HABs are reported to be increasing in the Indian waters. These blooms adversely affect the living resources, destroy coastal aquaculture and can even be fatal to humans. Taking these into consideration, Centre for Marine Living Resources and Ecology (CMLRE), Ministry of Earth Sciences commenced a national programme on monitoring HABs since 1998. This programme envisages extensive monitoring of HABs in the Indian EEZ, identification of causative toxic/harmful microalgal species, and dynamics of bloom formation, spread and crash and its ecological consequences on marine ecosystems.

\section{Materials and Methods}

Ministry of Earth Sciences has been conducting regular oceanic cruises for the surveillance, identification, enumeration, and ecology of HABs in the territorial waters and contiguous seas in the Indian EEZ. Samplings were made from 1880 stations onboard FORV Sagar Sampada during the period 1998-2010. From all these stations phytoplankton samples were collected by filtering $\sim 50$ litres of surface water through $20 \mu \mathrm{m}$ bolting silk. The filtrates were preserved in $1-3 \%$ neutralized formaldehyde solution. Microalgal samples were also collected from bloom areas and nonbloom patches. Quantitative and qualitative analysis of micro algae were carried out by using Sedgewick Rafter counting cell under a Nikon Eclipse microscope following standard identification keys [12]. Area of the bloom and mortality of fishes if any was estimated on the basis of visual observation. Vertical profiling of parameters, such as temperature, salinity, and density was done using Conductivity-TemperatureDepth profiler (CTD Seabird 911 plus). Sea Surface Temperature (SST) was measured by a bucket thermometer. Chlorophyll $a$ was measured spectrophotometrically using a double beam UV-Visible spectrophotometer [13]. Major nutrients like nitrite, nitrate, phosphate, and silicate were analysed onboard using a segmented flow Auto Analyzer (SKALAR) by following standard procedures [14]. Besides in situ algal bloom observations since 1998, chronological HAB events in the Indian EEZ reported by earlier researchers were also incorporated for analyzing the trend of $\mathrm{HAB}$ events from 1917 onwards.

\section{Results and Discussion}

Altogether, 422 species of microalgae were recorded from EEZ of India during the investigation. Among them, there were 219 species of diatoms, 179 species of dinoflagellates,

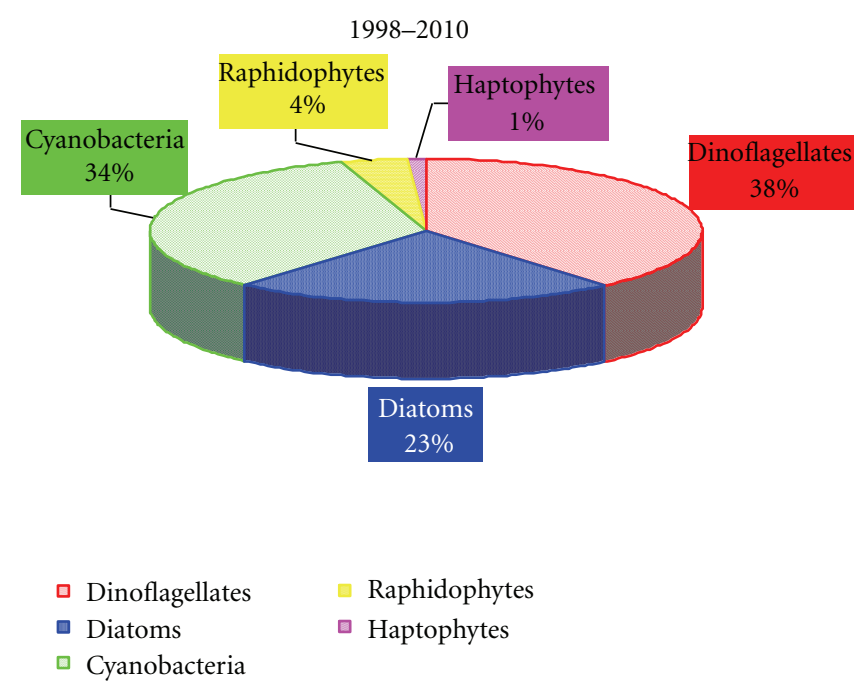

FIGURE 1: Groups of microalgae in percentage, contributing to the algal blooms during 1998 to 2010 .

16 species of blue green algae, and 8 other groups (silicoflagellates, chlorophytes, coccolithophorids, raphidophytes, haptophytes, and prasinophytes). Around 35 species of harmful microalgae have been recognized during the one-decadelong study period. Among the bloom forming species, during favourable conditions only a few species formed blooms. Around 80 algal blooms were recorded from the Indian EEZ during the period. Of the eighty algal blooms, 31 blooms were formed by dinoflagellates, cyanobacteria formed 27, and diatoms in 18 blooms. Three raphidophyte and one haptophyte blooms were also observed. The percentage composition of blooms by various groups of microalgae during the period $1998-2010$ is presented in Figure 1. Red Noctiluca scintillans (without endosymbiont Pedinomonas noctilucae) was the dominant and frequently occurring blooming dinoflagellate in the South Eastern Arabian Sea (SEAS) during the summer monsoon and green Noctiluca scintillans (with endosymbiont Pedinomonas noctilucae) in the North Eastern Arabian Sea (NEAS) during the winter cooling. Other commonly occurring bloom forming dinoflagellates were Cochlodinium sp., Gymnodinium sp., Gonyaulax sp., and Ceratium spp. The study reveals that the Trichodesmium bloom occurred annually, whereas the Noctiluca bloom appeared at irregular intervals.

Results obtained from the qualitative analysis of phytoplanktons over the years indicate that potentially toxic dinoflagellates were always present in the region. In particular, species responsible for several of the major shellfish poisoning syndromes have also been observed, these include Alexandrium catenella, Gymnodinium sp. (all implicated in Paralytic Shellfish Poisoning-PSP), Dinophysis acuminata, D. caudata, D. fortii, D. miles, D. tripos (all implicated in Diarrhetic Shellfish Poisoning (DSP) episodes), Coolia monotis, and Prorocentrum lima (causing Ciguatera poisoning). In addition, other harmful algal bloom species linked to fish and animal mortalities have been observed in Indian waters. Chattonella marina, Cochlodinium polykrikoides, 


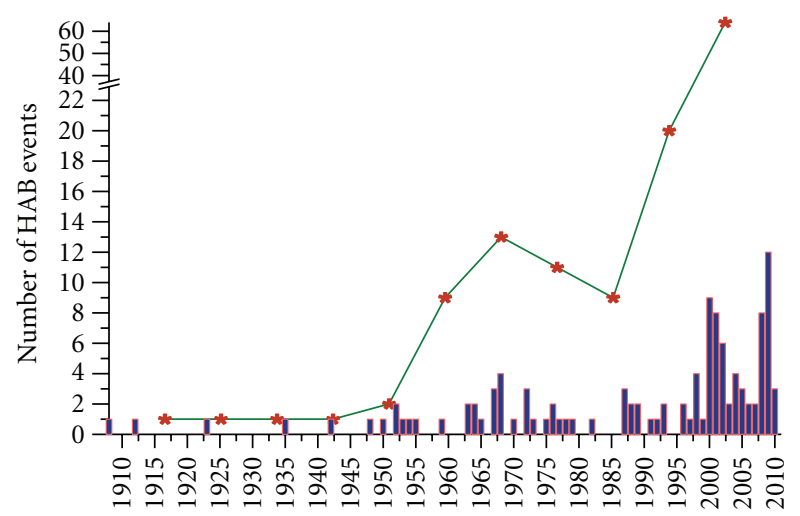

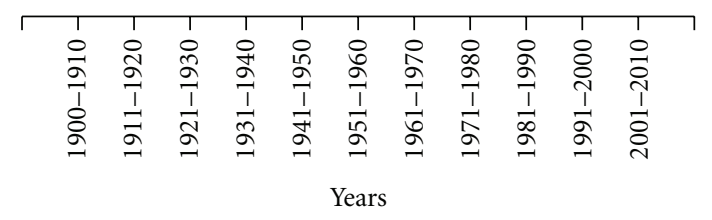

*** HAB events in 10 year interval

rearly HAB events

FIgURE 2: Frequency of occurrence of harmful algal blooms during the last century.

Gonyaulax sp., Ceratium sp., and several Prorocentrum species were found abundantly in the phytoplankton population. Notwithstanding these observations, only two cases of PSP $[9,11]$ and one case of DSP [15] were recorded earlier from the Indian waters.

The nature of the occurrence, preponderance, and successful existences for short duration of HABs has undergone noticeable changes during the last decade in the Indian EEZ. Previous reports of algal bloom occurrence in the Indian EEZ since 1917 and in situ bloom observations during 1998 to 2010 were analysed to explain whether there is an increase in the $\mathrm{HAB}$ events, the results obtained are presented in Figures 2, 3, and 4. A major change in the $\mathrm{HAB}$ studies in the Indian Seas in the last two decades is the conduct of detailed ocean cruises to delineate the areas in the exclusive economic zone where the HAB events occur. This was due to the occurrence of shellfish poisoning events in the coastal communities due to the consumption of contaminated shellfish [9]. The media has become very vigilant and occurrence of toxic/harmful algal blooms is immediately reported by the local press in all coastal states especially Kerala.

Atmospheric nitrogen fixing Trichodesmium erythraeum is the only bloom forming cyanophycean member in the Indian waters. Presence of Trichodesmium blooms along the southwest coast during the premonsoon indicates the nitrogen recycling process in the ocean. Several reports [16-22] explained the regular occurrence of Trichodesmium blooms in the Arabian Sea during the period from January to June. From the present investigation it has come to light that the occurrence and intensity of Trichodesmium blooms has increased in the recent past in Indian EEZ especially in the Arabian Sea. According to Naqvi and Sen Gupta [23] Arabian Sea became nitrate deficient due to denitrifications. Nitrogen limitation in upwelling regions is a natural consequence of nitrogen gas loss through $\mathrm{N}_{2}$ production [24-26]. Therefore, the regions of intense upwelling generate oxygen depleted waters with $\mathrm{N}_{2}$ production in the subsurface waters. Hence the primary production in surface waters at these areas is often nitrogen limited probably triggering blooms of cyanobacteria species capable of fixing atmospheric nitrogen. According to Prasannakumar et al. [27] there is an increase in the SST of Arabian Sea $\left(\mathrm{ca} 0.2^{\circ} \mathrm{C}\right)$ and is attributed to climate change and global warming. Generally the bloom of this filamentous algae occurred during hot weather with brilliant sunlight and stable high salinity [28, 29]. It is clear from these reports and our in situ studies that the Arabian Sea has become both nitrogen deficient and warmer, causing recurrent blooming of Trichodesmium in the area.

Reports on diatom blooms were meagre in the Indian EEZ during the period 1917-1997 [30-35]. In the present investigation (1998-2010) diatom blooms were observed in a number of occasions in the coastal waters and these were caused by Coscinodiscus spp., Proboscia alata, Rhizosolenia spp., Fragilaria oceanica, Thalassiosira spp., Chaetoceros spp., and Asterionella japonica. Upwelling, formation of mud banks, estuarine discharge, and land run off during southwest and northeast monsoons cause eutrophication in the coastal waters triggering the flowering of diatoms which responds faster to eutrophication. Toxic diatom species Psuedo-nitzschia multiseries, $P$. australis and $P$. seriata, collected during the investigation have the ability to produce potent neurotoxin Domoic acid. Psuedo-nitzschia sp. is known to produce domoic acid (DA), a potent neurotoxin that can be devastating to aquatic life via trophic transfer in the food web [36-38]. In humans, DA exposure manifests itself as amnesic shellfish poisoning (ASP) following the consumption of contaminated filter-feeding molluscs [39, 40]. Toxin production in Pseudo-nitzschia species has been found to show regional variations. Thus the same Pseudonitzschia species may be toxic in one part of the world but not in the other [37]. During this study Pseudo-nitzschia sp. was recorded from Malabar coast which is a famous shellfish harvesting ground along the west coast of India. The occurrence of toxigenic Pseudo-nitzschia species along our coasts is of concern, as it is possible that Pseudo-nitzschia spp. in the diet can result in the accumulation of domoic acid in the wild and cultured population of bivalve molluscs of the coast. Inshore waters of southwest coast of India is recently (2008 and 2009) experiencing high chlorophyll $a$ concentration $\left(10-25 \mathrm{mg} \mathrm{m}^{-3}\right)$, due to the localized blooms of diatoms during the southwest monsoon period from late May to October (from FORV Sagar Sampada Data centre). These are monospecific and mixed blooms by the diatom genera such as Chaetoceros, Asterionella, Thalassiosira, Skeletonema, Thalassiothrix, Rhizosolenia and Proboscia.

The raphidophyte flagellate, Chattonella marina (Subrahmanyan) Hara et Chihara is a well-known causative organism of red tides and associated mass mortality of marine fauna throughout the world oceans $[41,42]$. The bloom forming harmful raphidophycean species C. marina, produces neurotoxin, which in nanomolecular concentrations is toxic to fishes. During the present study C. marina bloom 


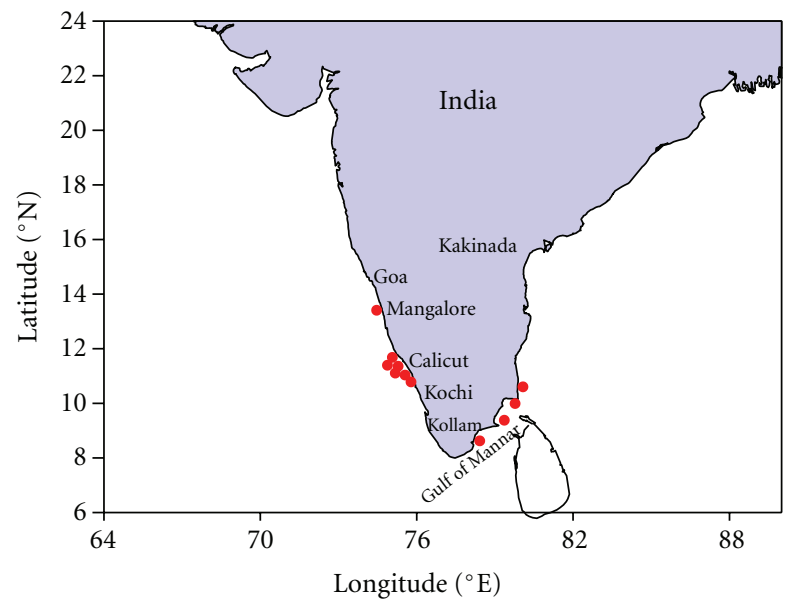

(a) 1917-1957

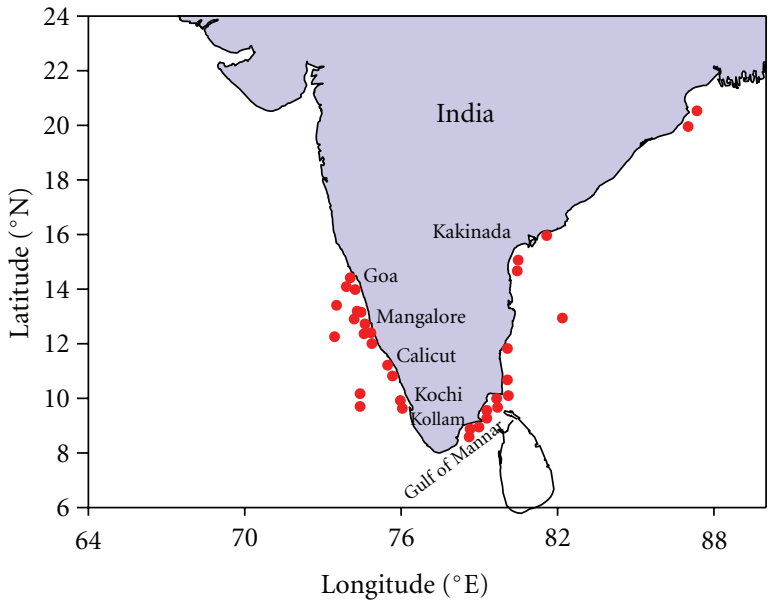

(b) 1958-1997

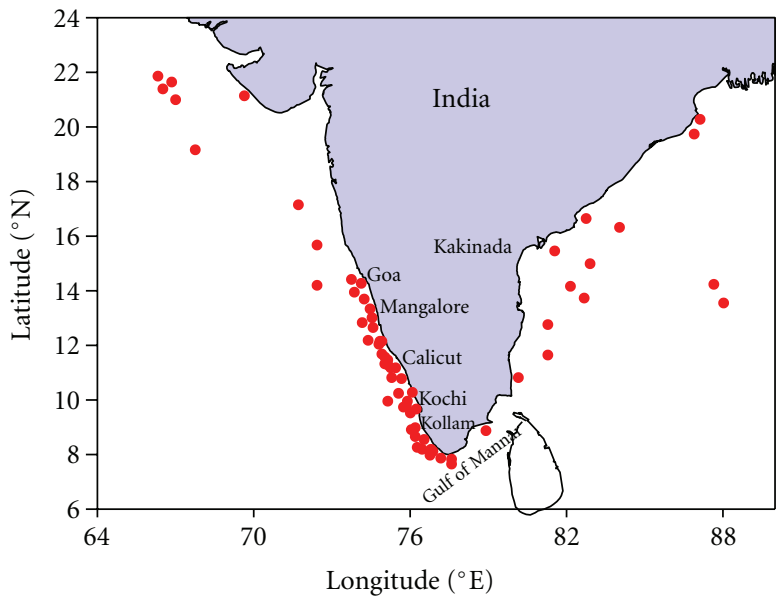

(c) $1998-2010$

FIgURE 3: Trend figures indicating increasing incidence of harmful algal blooms in the Indian EEZ from 1917 to 2010 (red dots represent each algal blooms observed).

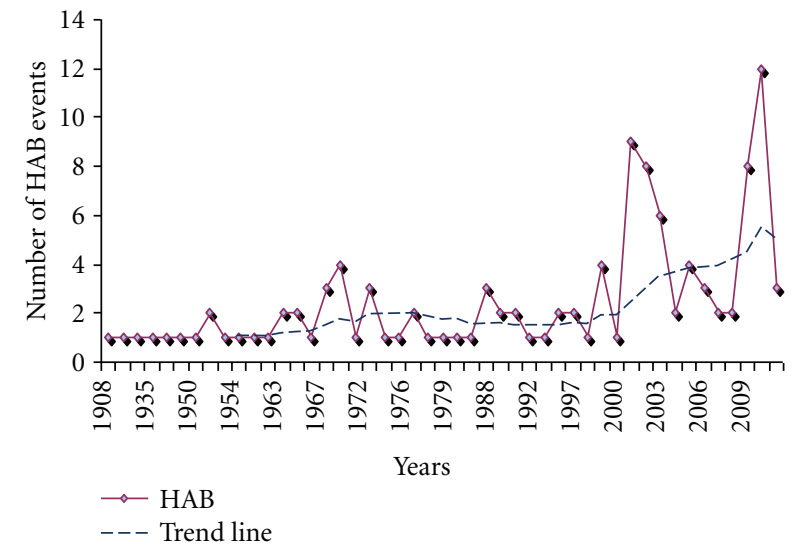

Figure 4: Trend line and harmful algal bloom events (actual observation) from 1908 to 2010 .

and associated mortality of marine fauna was observed off Kochi during the monsoon season of 2002 and 2009. All these recorded toxic microalgae are capable of producing toxins at very low densities (100 to 1000 cells L ${ }^{-1}$ ). The employment of scanning electron microscopy and transmission electron microscopy has been resorted to identify the species more precisely. The species capable of producing toxins are of nanoplankton size $(<20 \mu \mathrm{m})$ and demands critical examination by electronmicroscopy. This is highly essential because the study of shellfish poisoning in the laboratory could be carried out only if the species capable of producing such toxins are identified [43]. These developments in the recognition of HABs in the Indian waters have created very good awareness about this phenomenon among the coastal community. Around 3.5 million fisherfolks depend on the fish and fish products for their livelihood in the region.

The dinoflagellate genus Pyrophacus has three species with comparable cellular morphology and cosmopolitan distribution. One of the species Pyrophacus steinii (Schiller) Wall and Dale is reported from Indian EEZ in sparse quantities. A subsurface bloom of Pyrophacus steinii was recorded off Mangalore during the fag end of summer monsoon (September-October, 2009). The presence of the bloom was not reflected by any conspicuous surface water discolouration. A high cell density of $7.75 \times 10^{5}{\text { cells } \mathrm{L}^{-1}}^{-1}$ 
was recorded in the entire bloom area which was spread over a large area $10 \mathrm{~m}$ below surface. P. steinii cells are flattened, lenticular with attenuated epitheca and numerous golden brown chloroplasts. The phytoplankton population of the bloom area was composed of Pyrophacus steinii (94\%) and other phytoplankters such as Chaetoceros spp., Thalassiosira sp., Rhizosolenia spp., Pseudo-nitzschia sp., and Ceratium spp. although present only in very low numbers. The chlorophyll $a$ concentration of the bloom area was $26.47 \mu \mathrm{g} \mathrm{L}^{-1}$. Nutrient concentration of the bloom area was $0.04 \mu \mathrm{mol} \mathrm{L}^{-1} \mathrm{NO}_{2}-\mathrm{N}, 0.13 \mu \mathrm{mol} \mathrm{L}^{-1} \mathrm{NO}_{3}$ $\mathrm{N}, 1.72 \mu \mathrm{mol} \mathrm{L}^{-1} \mathrm{PO}_{4}-\mathrm{P}$, and $3.90 \mu \mathrm{mol} \mathrm{L}^{-1} \mathrm{SiO}_{4}$. There is no report about the harmful effects of this species. This observation on Pyrophacus steinii bloom in the Arabian Sea is unique in character and is the first record of its kind from the world oceans.

An examination of the trend line clearly depicts around $15 \%$ increase in the frequency of algal blooms in the Indian seas during the last twelve years. Further, the occurrence of algal blooms in the Arabian sea and Bay of Bengal shows that Arabian sea experiences more number of algal blooms. Bay of Bengal has recorded bloom by and large during the northeast monsoon period when cyclonic storms occur in this region. This probably is indicative of the fact that should the wind effects affect the circulation pattern of the upper ocean layers, global warming and the resultant storminess could influence the frequency of bloom formation in the Indian seas. Qualitative studies from 1998-2010 have shown that at least two species hitherto not recorded as bloom formers have staged their appearance. This could be an instance of blooming of innocuous species which could be due to eutrophication of coastal waters or introduction of bloom formers in the open sea due to ballast water discharge.

\section{Conclusion}

Phytoplankton blooms are known from ancient times but it requires an effort and expertise to properly investigate and accurately identify the bloom forming species. Harmful algal blooms have become a global epidemic. Increase in harmful algal bloom events in the Indian waters could be due to increase in anthropogenic enrichment of the coastal environment or other eutrophication such as increased coastal aquacultural farming, discharge of ballast water drawn from coastal ports, and so forth. The types of resources affected and the quantity of toxins and toxic species encountered have increased. The results clearly indicate that occurrence of HABs is on the rise in quality and quantity in the recent years. The time and duration that HABs occur annually may also expand as a result of climate change. Water temperature when on the rise can promote growth of toxic algae especially dinoflagellates. No serious attempts have been made so far, to find out the influence of ballast water discharge on the occurrence of HABs, but for a record by Madhu et al. [44]. The extensive occurrence of a single species both spatially and temporally necessitates investigation on the possibility of physiological races of the same species occurring in a wider area [43]. In the case of the west coast of India, considerable increase in the number of blooms that appeared during the last decade clearly points towards the necessity for closer monitoring of the hydrology of the region which is one of the richest habitat for pelagic fishery.

Dinoflagellates are capable of movement and hence can seek deeper layers for nutrients to overcome surface nutrient impoverisation. This may lead to increased number of HABs as a result of climate change when upper stratification of surface layers occurs. Of late epidemiological studies to demonstrate the effects of algal toxins on human health have been undertaken. However, laboratory experiments to study the toxicity of bloom forming algae on shellfish from Indian waters is totally lacking and requires immediate attention as shellfish culture along the Indian coast is increasing rapidly. It is necessary to accurately identify and establish early monitoring programmes in order to decrease the negative impact of HAB. The effects of these blooms in seafood quality, economic liabilities on fisherfolks, correct assessment of factors triggering blooms, and subsequent effects in the trophodynamics are areas which need elaborate studies.

\section{Acknowledgments}

The authors are thankful to all the participants of FORV Sagar Sampada cruises from 1998 to 2010. We are also grateful for the comments and suggestions made by anonymous reviewers who helped to improve the manuscript. This observation was made under the Marine Living Resources Programme funded by the Ministry of Earth Sciences, Government of India, New Delhi.

\section{References}

[1] ICES, "Report of the ICES special meeting on the causes, dynamics and effects of exceptional marine blooms and related events," International Council Meeting Paper 1984/ E, 42, ICES, 1984.

[2] T. J. Smayda and A. W. White, "Has there been a global expansion of algal blooms? If so is there a connection with human activities?" in Toxic Marine Phytoplankton, E. Granelli, Ed., p. 516, Elsevier, 1990.

[3] G. M. Hallegraeff, "A review of harmful algal blooms and their apparent global increase,” Phycologia, vol. 32, no. 2, pp. 79-99, 1993.

[4] F. M. Van Dolah, "Marine algal toxins: origins, health effects, and their increased occurrence," Environmental Health Perspectives, vol. 108, no. 1, pp. 133-141, 2000.

[5] J. Hornell, "A new protozoan cause of widespread mortality among marine fishes," in Madras Fisheries Investigations Bulletin, vol. 11, pp. 53-56, 1917.

[6] R. Subrahmanyan, "On the life history and ecology of Hornellia marina gen. et sp. Nov., (Chloromonadineae), causing green discoloration of the sea and mortality among marine organisms off the Malabar coast," Indian Journal of Fisheries, vol. 1, pp. 182-203, 1954.

[7] Y. Hara and M. Chihara, "Ultra structure and taxonomy of Chattonella (class Raphidophyceae) in Japan," Japanese Journal of Phycology, vol. 30, pp. 47-56, 1982. 
[8] V. P. Devassy and S. R. Bhat, "The killer tides," Science Reporter, vol. 28, no. 5, pp. 16-19, 1991.

[9] I. Karunasagar, H. S. V. Gowda, M. Subhurah, M. N. Venugopal, and I. Karunasagar, "Outbreak of paralytic shellfish poisoning in Mangalore, west coast of India," Current Science, vol. 53, p. 247, 1984.

[10] A. Godhe and I. Karunasagar, "Gymnodinium catenatum on west coast of India," Harmful Algae News, vol. 15, p. 1, 1996.

[11] I. Karunasagar, B. Joesph, K. K. Philipose, and I. Karunasagar, "Another outbreak of PSP in India," Harmful Algae News, vol. 17, p. 1, 1998.

[12] C. R. Tomas, Identifying Marine phytoplankton, Academic press, New York, NY, USA, 1997.

[13] T. R. Parsons, Y. Maita, and C. M. Lalli, A Manual of Chemical and Biological Methods for Seawater Analysis, Pergamon Press, New York, NY, USA, 1984.

[14] UNESCO, "Protocols for the Joint Global Ocean Flux Study (JGOFS), core measurements," in IOC Manual and Guides, vol. 29, p. 170, 1994.

[15] R. Santhanam and A. Srinivasan, "Impact of dinoflagellate Dinophysis caudata bloom on the hydrography and fishery potentials of Tuticorin Bay, South India," in Harmful and Toxic Algal Blooms, T. Yasumoto, Y. Oshima, and Y. Fukuyo, Eds., pp. 41-44, IOC-UNESCO, Sendai, Japan, 1996.

[16] N. K. Panikar, "Indian fisheries," Current Science, vol. 28, no. 12, pp. 53-54, 1959.

[17] A. K. Nagabhushanam, "On an unusually dense phytoplankton bloom around Minicoy Island (Arabian Sea), and its effect on the local tuna fisheries," Current Science, vol. 36, no. 22, pp. 611-612, 1967.

[18] S. Z. Qasim, "Some characteristics of a Trichodesmium bloom in the Laccadives," Deep Research-II, vol. 17, no. 3, pp. 655$660,1970$.

[19] R. K. Sarangi, P. Chauhan, and S. R. Nayak, "Detection and monitoring of Trichodesmium blooms in the coastal waters off Saurashtra coast, India using IRS-P4 OCM data," Current Science, vol. 86, no. 12, pp. 1636-1641, 2004.

[20] R. K. Sarangi, P. Chauhan, S. R. Nayak, and U. Shreedhar, "Remote sensing of Trichodesmium blooms in the coastal waters off Gujarat, India using IRS-P4 OCM," International Journal of Remote Sensing, vol. 26, no. 9, pp. 1777-1780, 2005.

[21] A. A. Krishnan, P. K. Krishnakumar, and M. Rajagopalan, "Trichodesmium erythraeum (Ehrenberg) bloom along the Southwest coast of India (Arabian Sea) and its impact on trace metal concentrations in seawater," Estuarine, Coastal and Shelf Science, vol. 71, no. 3-4, pp. 641-646, 2007.

[22] K. B. Padmakumar, B. R. Smitha, L. C. Thomas et al., "Blooms of Trichodesmium erythraeum in the South Eastern Arabian Sea during the onset of 2009 summer monsoon," Ocean Science Journal, vol. 45, no. 3, pp. 151-157, 2010.

[23] S. W. A. Naqvi and R. Sen Gupta, "NO, a useful tool for the estimation of nitrate deficits in the Arabian Sea," Deep Sea Research Part A, vol. 32, no. 6, pp. 665-674, 1985.

[24] R. Dugdale, J. Goering, R. Barber, R. Smith, and T. Packard, "Denitrification and hydrogen sulfide in the Peru upwelling region during 1976," Deep Sea Research, vol. 24, no. 6, pp. 601$608,1977$.

[25] C. Mantoura, R. F. C. Fauzi, C. S. Law et al., "Nitrogen biogeochemical cycling in the Northwestern Indian Ocean," Deep Sea Research Part II, vol. 40, no. 3, pp. 651-671, 1993.

[26] A. G. Davies and C. E. Morales, "An appraisal of the stoichiometry of dissolved oxygen/nutrient inter-relationships in the upwelling system off Northern Chile," Journal of the
Marine Biological Association of the United Kingdom, vol. 78, no. 3, pp. 697-706, 1998.

[27] S. Prasannakumar, R. P. Roshin, J. Narvekar, P. K. Dineshkumar, and E. Vivekanandan, "Response of the Arabian Sea to global warming and associated regional climate shift," Marine Environmental Research, vol. 68, no. 5, pp. 217-222, 2009.

[28] S. Suvapepant, "Trichodesmium blooms in gulf of Thailand," in Marine Pelagic Cyanobacteria: Trichodesmium and Other Diazotrophs, E. J. Carpenter, D. G. Capone, and J. G. Rueter, Eds., pp. 343-348, Kluwer Academic publisher, 1992.

[29] K. G. Sellner, "Physiology, ecology, and toxic properties of marine cyanobacteria blooms," Limnology and Oceanography, vol. 42, no. 5, pp. 1089-1104, 1997.

[30] D. V. S. Rao, "Asterionella japonica bloom and discolouration off Waltair, Bay of Bengal," Limnology and Oceanography, vol. 14, pp. 632-634, 1969.

[31] A. Subramanian and A. Purushothaman, "Hemidiscus hardmanianus bloom and fish mortality," Limnology and Oceanography, vol. 30, no. 4, pp. 910-911, 1985.

[32] K. K. Satpathy and K. V. K. Nair, "Occurrence of phytoplankton bloom and its effect on coastal water quality," Indian Journal of Marine Sciences, vol. 25, no. 2, pp. 145-147, 1996.

[33] S. B. Choudhury and R. C. Panigrahy, "Occurrence of bloom of diatom Asterionella glacialis in near shore waters of Gopalpur, Bay of Bengal," Indian Journal of Marine Sciences, vol. 18, pp. 204-206, 1989.

[34] R. C. Panigrahy and R. Gouda, "Occurrence of bloom of the diatom Asterionella glacialis (Castracane) in the Rushikulya estuary, East Coast of India," Mahasagar, vol. 23, no. 2, pp. 179-182, 1990.

[35] S. Mishra and R. C. Panigrahy, "Occurrence of diatom blooms in Bahuda estuary, east coast of India," Indian Journal of Marine Sciences, vol. 24, pp. 99-101, 1995.

[36] L. Fritz, M. A. Quilliam, J. L. C. Wright, A. M. Beale, and T. M. Work, "An outbreak of domoic acid poisoning attributed to the pennate diatom Pseudonitzschia australis," Journal of Phycology, vol. 28, no. 4, pp. 439-442, 1992.

[37] S. S. Bates, D. L. Garrison, and R. A. Horner, "Bloom dynamics and physiology of domoic acid- producing Pseudo-nitzschia species," in Physiological Ecology of Harmful Algal Blooms, D. M. Anderson, A. D. Cembella, and G. M. Hallegraeff, Eds., p. 267, Springer, Heidelberg, Germany, 1998.

[38] C. A. Scholin, F. Gulland, G. J. Doucette et al., "Mortality of sea lions along the central California coast linked to a toxic diatom bloom," Nature, vol. 403, no. 6765, pp. 80-83, 2000.

[39] S. S. Bates, C. J. Bird, A. S. W. de Freitas et al., "Pennate diatom Nitzschia pungens as the primary source of domoic acid, a toxin in shellfish from eastern Prince Edward Island, Canada," Canadian Journal of Fisheries and Aquatic Sciences, vol. 46, no. 7, pp. 1203-1215, 1989.

[40] V. L. Trainer, W. P. Cochlan, A. Erickson et al., "Recent domoic acid closures of shellfish harvest areas in Washington State inland waterways," Harmful Algae, vol. 6, no. 3, pp. 449-459, 2007.

[41] Y. Onoue and K. Nozawa, "Separation of toxin from harmful red tides occurring along the coast of Kagoshima Prefecture," in Red Tides-Biology, Environmental Science and Toxicology, T. Okaichi, D. M. Anderson, and T. Nemeto, Eds., pp. 371-374, Elsevier, New York, NY, USA, 1989.

[42] T. Oda, A. Ishimatsu, S. Takeshita, and T. Muramatsu, "Hydrogen peroxide production by the red tide flagellate Chattonella marina," Bioscience Biotechnology and Biochemistry, vol. 58, pp. 957-958, 1994. 
[43] K. B. Padmakumar, Algal blooms and Zooplankton standing crop along the South West coast of India, Ph.D. thesis, Cochin University of Science and Technology, Kerala, India, 2010.

[44] N. V. Madhu, P. D. Reny, M. Paul, N. Ullas, and P. Resmi, "Occurrence of red tide caused by Karenia mikimotoi (toxic dinoflagellate) in the Southwest Coast of India," Indian Journal of Geo-Marine Sciences, vol. 40, no. 6, pp. 821-825, 2011. 

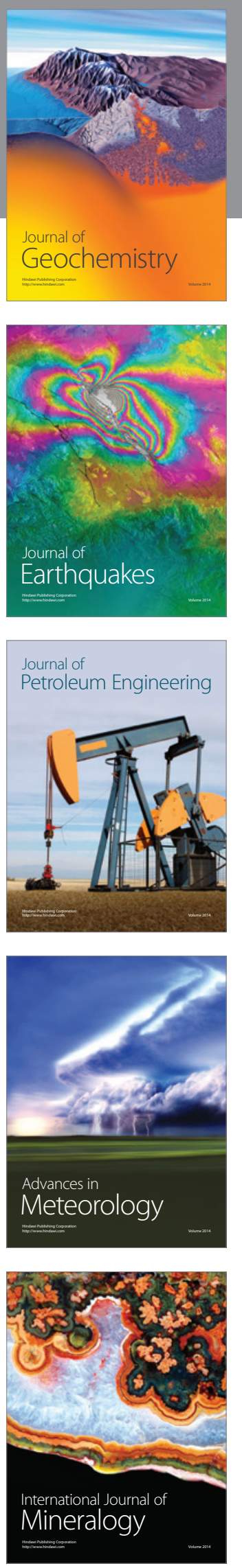
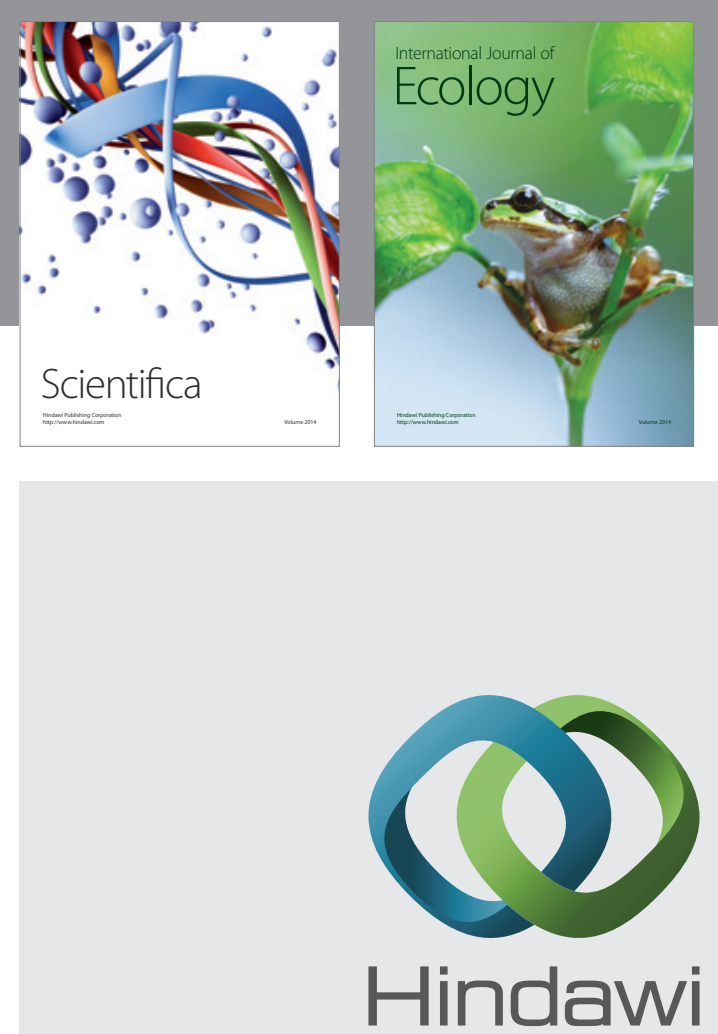

Submit your manuscripts at http://www.hindawi.com
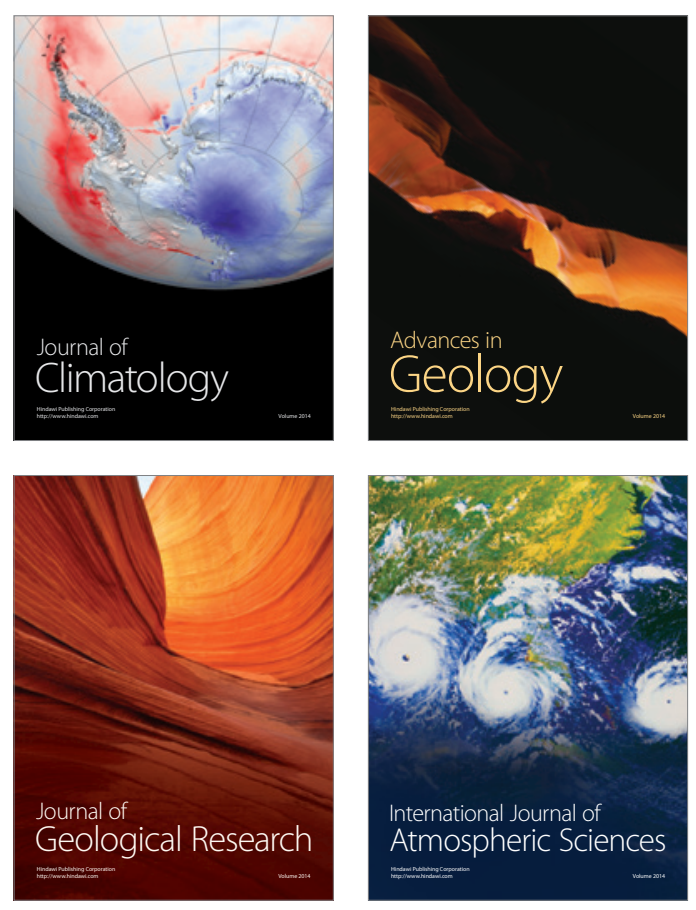
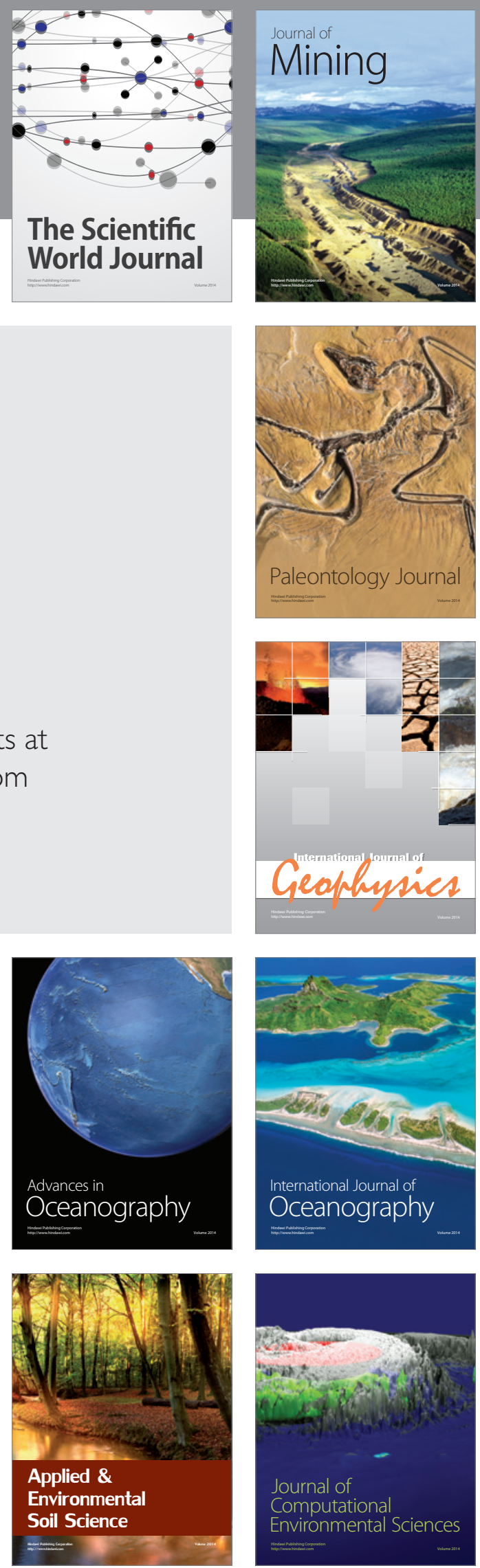